\title{
The Utilization of Instructional Processes in Higher Education Institutions of the Amhara Region, Ethiopia
}

\author{
Tadesse Melesse
}

Department of Teacher Education and Curriculum Studies, Faculty of Education and Behavioral Sciences, Bahir Dar University, P.O. Box: 79, Bahir Dar, Ethiopia

\begin{tabular}{|c|c|}
\hline & Article Information \\
\hline \multirow{3}{*}{$\begin{array}{l}\text { This study focused on re-visiting the instructional processes in Universities and Colleges of } \\
\text { Teacher Education (CTEs) of the Amhara Region, Ethiopia. The research design was of } \\
\text { descriptive survey type and data were obtained from } 204 \text { instructors, department heads and } \\
\text { deans. Both University and CTE instructors' practices of the instructional processes and their } \\
\text { conceptions on effective teaching were examined. Results indicated that in order to bring } \\
\text { learning into effect, the three interactive instructional processes (instructional planning, } \\
\text { teaching and assessment) were not adequately implemented in an integrated manner. } \\
\text { Significant differences were observed between Universities and CTEs in the application of } \\
\text { instructional planning and various continuous assessment techniques. CTEs were in a good } \\
\text { position than universities. However active learning strategies that enhance higher order } \\
\text { thinking and assessment for learning were not adequately applied in both institutions. } \\
\text { Attitudinal problems, lack of knowledge, work load and shortage of time were taken as } \\
\text { factors affecting the instructional processes in Universities and CTEs. } \\
\text { Coopyright@2015 STAR Journal, Wollega University. All Rights Reserved. }\end{array}$} & $\begin{array}{l}\text { Article History: } \\
\text { Received : } 02-10-2015 \\
\text { Revised : } 24-12-2015 \\
\text { Accepted : } 26-12-2015\end{array}$ \\
\hline & $\begin{array}{l}\text { Keywords: } \\
\text { Instructional process } \\
\text { Instructional planning }\end{array}$ \\
\hline & $\begin{array}{l}{ }^{*} \text { Corresponding Author: } \\
\text { Tadesse Melesse }\end{array}$ \\
\hline
\end{tabular}

\section{INTRODUCTION}

Recent scholarly reports stress the importance of enhancing quality education and placing the most qualified teachers in the classroom in order to provide the best education for students. In the last two decades, many countries around the world introduced reforms in education aimed at enhancing the quality of education and preparing individuals capable of competing in an increasingly scientifically and technologically oriented global economy (Thomson and Mclntyre, 2013). Quality levels vary widely from one education system to another and, within a single education system there may be sharp variations in quality (UNESCO, 2006). This unevenness of quality is therefore a critical issue facing education systems. Such different pressures have resulted in the concept of the 'quality of education' and 'teacher quality' coming to the fore as learners, parents and communities, educators, leaders, and nations acknowledge that what is learned and how learning occurs is as important as access to education (UNESCO,2006).

The concept of 'teacher quality' has not been adequately defined (Bryk, Harding and Greenberg, 2012) and the effects of the ingredients of teacher quality including teachers' qualification, experience, test scores, classroom practice, and attitude (Goe, 2007) are neither adequately studied nor empirically established. However, there is a wider consensus that 'teacher quality' is an aspect of effective teaching which can translate into student achievement (Bryk et al., 2012). Similarly, there exists a vast and varied repertoire of concepts, skills, and techniques that purport to make teaching more effective for students' learning (Darling-Hammond et al., 2007; Farr, 2010; Lemov, 2010).

Thus, in the context of Higher Education, effective teaching is about reaching achievement goals; it is about students learning in a particular context, grade or subject through quality instruction (Berliner, 2005). Research into effective teaching (Entwistle, 2000; Shuman, 2002; Warren Little, 2003 in Reece and Walker, 2003) illustrates that quality instruction involves instructional planning and managing learning effectively, use a variety of active learning strategies and promoting and actively engaging in professional and personal development continually and evaluating students' learning experiences. In other words, instructional process comprises three basic interactive components (planning, teaching and assessment) that are aligned one another (Brookhart, 2004; Brookhart, 1999; Clarke, 2005; Reeves, 2006). According to Reeves (2006) alignment of the instruction is essential and success of any learning environment is determined by the degree to which there is adequate alignment among eight critical factors: 1) goals, 2) content, 3) instructional design, 4) learner tasks, 5) instructor roles, 6) student roles, 7) technological affordances, and 8) assessment (Reeves, 2006). Failure to align these dimensions will undermine the successful design and implementation of the instruction (Reeves, 2006). 
Tadesse Melesse

In the instructional process, the first task of teacher or instructor is planning learning (Reece and Walker, 2003). Planning involves the formulation of instructional objectives, processes and learning outcomes which leads to decisions about the types of learning activities that will enable students to successfully achieve the required outcomes (Darling-Hammond and Bransford, 2005; Gronlund, 2006). The second task is teaching. In a contemporary Higher Education context, effective teaching is enabling learners to become an independent learner, develop meta-cognitive skills, solve problems, act on feedback, assess one's strengths and weaknesses, acquire generic study skills, make effective use of technology to promote one's own learning, work effectively with others, and efficient time-management (Allan and Clarke, 2007). Thus, the student-centered approach, focusing on the process of learning rather than the product (Zhang, 2003), is a central idea for effective teaching. As a third task, integral to the concept of objective setting and methods of teaching, is assessment (Clarke, 2005; Reeves, 2006; Sperber, 2005). Assessment (mainly continuous assessment) is a strategy used by teachers to support the attainment of goals and skills by learners over a period of time (Clarke, 2005; Reeves, 2006). It provides regular information about teaching-learning, the achievement of learning objectives and competencies (Reece and Walker, 2003; Reeves, 2006; Sperber, 2005; USAID, 2010). Continuous assessment, mainly formative assessment, is therefore seen as an integral aspect of the teaching and learning cycle (Bain, 2004; Fry et al, 2004; Wiliam and Thompson, 2008). As Bain (2004) stated, best teachers in higher education use assessment "to help students learn, not just rate and rank their efforts" $(p, 151)$.

Currently, in Higher Education, there is a shift from teacher centered to learner centered approach, from teaching to learning and from summative assessment to formative assessment. Despite the shift in conceptions of teaching and learning, a parallel shift in relation to formative assessment and feedback has been slower to emerge (Yorke, 2003). Dryden and Vos (2005) point out that many educators throughout the world are still
Sci. Technol. Arts Res. J., Oct-Dec 2015, 4(4): 182-193

teaching in ways similar to the blackboard-and-chalk, desk-in-rows classroom model and formative assessment and feedback are still largely controlled by and seen as the responsibility of teachers.

Although in general higher education practice, innovative approaches to teaching are more the exception than the rule, there are good examples in the higher education literature of undergraduate courses where an appropriate level of alignment among objectives, methods of teaching and assessment have been reached (Bain, 2004; Reeves, 2006). But the weakest component of most designs is assessment, perhaps because both instructors and students are so accustomed to thinking of assessments in traditional ways (Reeves, 2006). An effective teacher/instructor starts with what he/she wants his/her students learn (the objectives), goes through 'entry behavior' (what the student already knows about the topic), teaching methods (this involves experiences and reflections), and assesses how much has been learned and finally provides the feedback (Gronlund, 2006; Reece and Walker, 2003).

\section{Conceptual Framework}

From this frame work an effective teacher/instructor should first plan the lesson, deliver the lesson per the plan and assess whether students are achieving the expected objective or not. Based on the assessment results feedback should be provided for further improvement. It is these aligned process that helps students' learning achievement. In the impact of evaluating effective constructivists' teaching, Reece and Walker (2003) stated that instructional planning, teaching methods and assessment has direct relationships. Nevertheless, in contexts where traditional methods of teaching are the norm, assessment are also often highly traditional. In subSaharan Africa, for example, teachers are authoritarians "who expect students to listen and memorize correct answers or procedures rather than construct knowledge themselves" (Akyeampong et al., 2006:155). Similarly, most Ethiopian classrooms still are teacher centered, where informative instruction is the norm (Joshi and Verspoor, 2013)

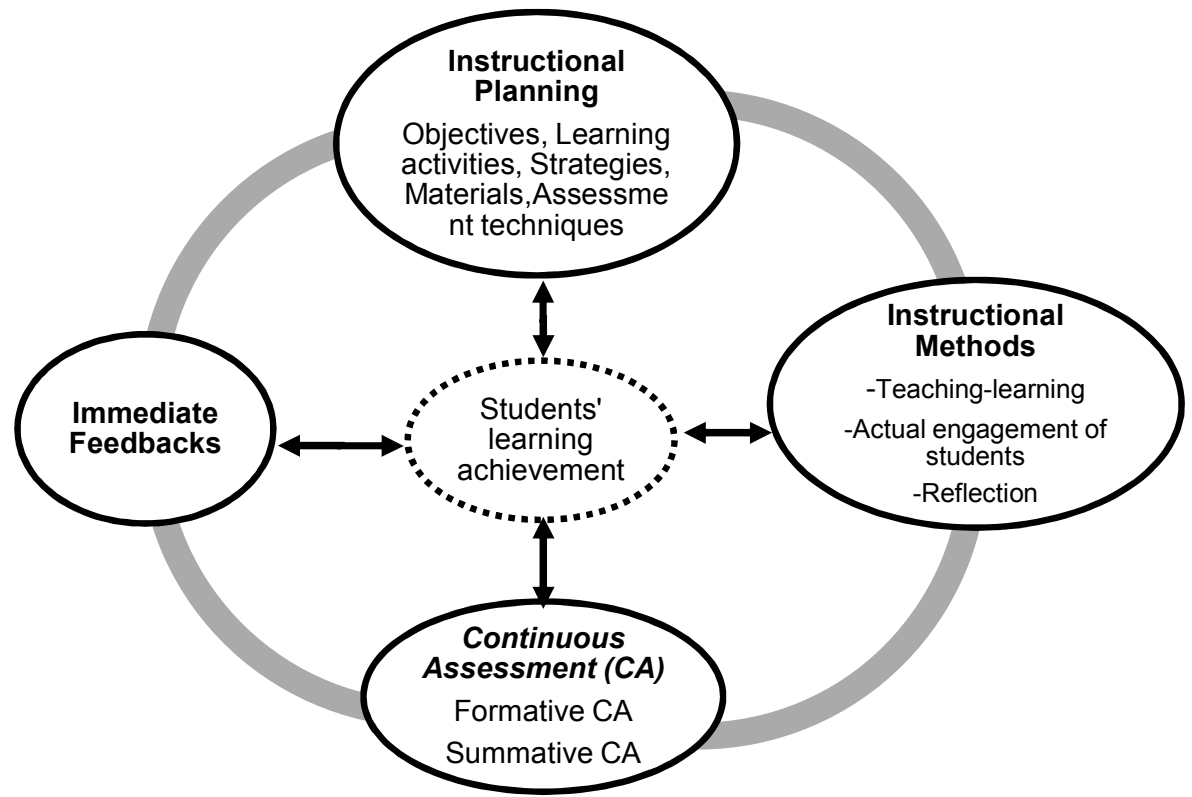

Figure 1: Conceptual framework of the study 


\section{Tadesse Melesse}

In spite of the rapid expansion of education in general, and higher education in particular, the Ethiopian education system has been experiencing complex hurdles with longterm social, economic, and political implications (Tesfaye, 2014). The lack of genuine commitment to address the glaring problems of education quality in general and the quality of teacher education in particular, seem to manifest faster than many observers might have predicted (Tesfaye, 2014). Similarly, according to the MoE (2003) study, teacher education in Ethiopia characterized a number of problems such as: the professional competence of teachers is deficient; their content knowledge is unsatisfactory; the teaching skills and techniques are very low; the quality of courses and methods of teaching are theoretical and teacher centered; there is lack of professionalism; and teachers do not match up to the standards and expectations of their professions.

Still the Ethiopian classrooms remain teacher centered (Joshi and Verspoor, 2013). The instructional practices in the universities and colleges are widely teacherdominated and content-oriented (Daniel, 2004; Joshi and Verspoor, 2013) and the current system of evaluating teaching effectiveness encourages such practices (Zenawi, 2009). There is no coherence and collaboration in the teacher education reforms and practices, and this is the reason for the apparent mismatch between the rhetoric in the country's teacher education policy and the reality of teacher education in training institutions and schools (Hussien, 2007). About the condition of teacher education in Ethiopia, Tessema (2006) cited in Hussien (2007) stated that at present, Ethiopian teacher education is characterized as a terrain of persistent contradictions, challenges, and chaos. Research on teaching-leaning process has also shown that students in higher institutions memorize specific facts and skills that help them to be promoted from one to another level of education (Reda, 2001). The majority of the institutions still teach their classes in the traditional lecture mode. Seventy one percent of university students indicated their role during the instructional process as passive listening to teachers' presentations (Zenawi et al., 2011).

High-quality teacher preparation requires planning, a complex body of knowledge, skills, dispositions, nurturing pedagogy, multiple forms of assessment (DarlingHammond et al., 2007; Goe, 2007; Huisheng, 2007; Osguthorpe, 2008). Good teaching, according to Osguthorpe (2008), requires a teacher to be knowledgeable in content, skilled in method, and virtuous in character. The teaching profession needs competent professionals with high concern and commitment for the social, psychological and intellectual prosperity of future citizens (Huisheng, 2007)

Due to this, the current reality of the education system as a whole, particularly teacher education, has become a source of considerable concern among educators, politicians, and the public at large (Tesfaye, 2014). In order to improve the teacher education program, a number of reforms were introduced and one of the reforms was Teacher Education System Overhaul (TESO) (MoE, 2003). TESO was expected to give a great premium to the creation of quality teachers who would transform the social, economic and political lives of the society (MoE, 2003). The overhaul assumes that teacher educators, with the capacity and commitment, are
Sci. Technol. Arts Res. J., Oct-Dec 2015, 4(4): 182-193

required to train transformative intellectuals and devote their time and energy to create informed citizens and have the initiative as well as the institutional support to play the transformatory role (Hussien, 2007).

Later on, despite its contributions, TESO was seriously criticized for marginalizing 'content knowledge' in its secondary teacher education program component (Dawit, 2008). The weaknesses of TESO were also expressed in terms of teachers' 'poor' attributes-inadequate subjectmatter knowledge, failure to apply student-centered or active learning methods, lack of interest to follow up and support students, low career commitment, and weak partnership of teachers with school leadership, parents, and the community at large (MoE, 2008; Tesfaye, 2014). Under such circumstances, graduates within the TESO program faced considerable difficulties in planning instruction, managing classrooms, and diagnosing students' learning needs (Tesfaye, 2014).

Currently, realizing the weaknesses of TESO and in order to bring quality education, a new reform for the teacher education programs called the Post Graduate Diploma in Teaching (PGDT) program swaps the TESO program (MoE, 2009). Priorities in this process include: improving the effectiveness of university programs for teachers and providing induction support to PostGraduate Diploma in Teaching (PGDT) are some to mention (Joshi and Verspoor, 2013; MoE, 2009). The main aim of PGDT was to fill the content and pedagogical gaps that were present in earlier secondary education teaching programs as observed in teaching and classroom practices in secondary schools (MoE, 2009; Joshi and Verspoor, 2013). In order to implement the program properly, both the Ministry of Education and the Amhara Regional Education Bureau (AREB) focused on Universities and College of Teacher Educations (CTEs) to exercise instructional planning, a variety of active learning methods and different continuous assessment techniques (MoE, 2009).

In order to improve teachers' and/ or instructors' instructional processes, frequent in-service trainings, Continuous Professional Development (CPD) and Higher Diploma Program (HDP) are in place. Besides, formative continuous assessment is also given emphasis to improve the teaching-learning process and students' achievement through continuous feedback (MoE, 2009). However, in practice, most instructors are not in a position to prepare instructional planning and implement different active learning strategies (Tadesse, 2012). Continuous assessment exercises in many programs are also poor at least in terms of giving feedback and in motivating further learning (Getachew, 2013; Singh, 2006; Zenawi, 2009; Zenawi et al., 2011). Similarly, from the researcher's exposure as an instructor, trainer, HDP leader and researcher, both in different Universities and CTEs of the Region, instructors were not properly delivering the instructional processes (preparing and applying instructional planning, delivering a variety of active learning strategies and applying different continuous assessment strategies). The main purpose of this study therefore was to assess instructors' practices of such instructional processes in Universities and CTEs of the Amhara Region.

Against the background of the contextual realities discussed above, the present study intended to answer 
Tadesse Melesse

the following key research questions: Firstly, to what extent do teacher educators of the Universities and CTEs apply the instructional processes (instructional planning, variety of active learning methods and continuous assessment techniques)? Secondly, is there a significant difference between and among Universities and CTEs in the application of the instructional processes? Thirdly, how do University and CTE instructors and principals conceive effective teaching? Fourthly, what are the factors that are affecting the implementation of the instructional processes in the Universities and CTEs?

\section{MATERIALS AND METHODS}

\section{Design of the Study}

For this study, descriptive survey research with mixed-methods design was applied. Mixed methods design is one in which both quantitative and qualitative methods are used to answer research questions in a single study (Creswell, 2012; Mertens, 2007). Mixed methods approach is useful to develop a better understanding of complex phenomena by triangulating one set of results with another and thereby enhancing the validity of inferences (Creswell, 2012; Johnson and Cristensen, 2008; Mertens, 2007). A combination of methods that have complementary strengths and non-overlapping weaknesses is the fundamental principle of mixed methods research. It is due to this argument that mixed approach is utilized (Denscombe, 2008).

Data were obtained from three Universities (Wollo, Woldia and Debre Tabor) and three CTEs (Dessie, Woldia and Begimeder) of the Amhara Region. From the three Universities, Social Science and Humanities faculty, Natural and Computational Science faculty and Educational and Behavioural Science faculty were obtained as sample areas. Two departments in each faculty of the universities and five departments of the three CTEs were taken as the sample areas. Finally, instructors and principals were taken as samples.

\section{Sampling Techniques}

Generally a multi-stage sampling technique was employed to select representative samples. Three Universities and three CTEs were selected purposely due to their proximity in location and the common tasks (like Higher Diploma Program) they have together. From the three Universities, three faculties were selected using purposive sampling. Two departments from each faculty i.e Mathematics and Biology from Natural and Computational Science faculty, Geography and English from Social Science and Humanities faculty and Psychology and Education departments from Educational and Behavioral Science faculty were selected using simple random sampling. On the other hand, five departments (Natural Science, Social Science, Professional Studies, Language and Aesthetics and
Sci. Technol. Arts Res. J., Oct-Dec 2015, 4(4): 182-193

Physical Education departments) from the three CTEs were chosen as samples using judgmental sampling.

Seven instructors from each department of the Universities and CTEs (a total of 231) were selected using simple random sampling. Out of these, twenty seven instructors who did not properly fill or return the questionnaire were deliberately discarded and only two hundred four instructors (101 from Universities and 103 from CTEs) were final samples. Moreover, deans and vice deans, department heads and Quality Assurance coordinators \& Teacher-Director-Supervisor coordinators were selected using snowball sampling.

\section{Data Gathering Tools and Methods of Analysis}

The main data gathering instruments were: questionnaire, semi-structured interviews, focus group discussion and document analysis. The questionnaire involves both close ended and open ended questions. Pilot study was conducted to test the reliability of the questionnaire for instructors in a single University and College. The reliability coefficient of the subscales of the questionnaire was computed using Chronbach alpha as 0.82 . Besides, items were checked by colleagues from the field of Measurement and Evaluation for its face validity. Documents such as prepared course plans, daily lesson plans, course guide books, course outlines and different continuous assessment results were also analyzed.

The collected data were analyzed and interpreted both quantitatively and qualitatively. To analyze quantitative data, graphs, percentage, mean, standard deviation, independent samples T-Test, and one Way-ANOVA were applied. Besides, the interview, focus group discussion and document review data were analyzed qualitatively using thematic analysis and descriptive analysis.

\section{RESULTS AND DISCUSSION}

In this part discussions in relation to reviewed literature were made. Since similar issues were categorized into themes and analyzed in a holistic perspective. The themes categorized were: instructional planning, active learning, continuous assessment and conceptions on effective teaching.

\section{Instructional Planning}

Instructional planning is one of the prior tasks to be considered by higher education institutions. Thus comparisons were made between Universities and CTEs regarding the use of instructional planning.

There was a significant difference on the utilization of instructional planning between Universities and CTEs. $\left(\mathrm{t}=8.709^{*}, P<0.05\right.$ at $\left.\mathrm{df}=202\right)$. That is, the mean value of CTEs (42.82) is greater than Universities (37.31) indicating that CTEs were found to be more effective in utilizing the instructional planning than the Universities (Table 1).

Table 1: Mean difference of instructors of CTEs and Universities in the application of instructional planning (Independent Samples t-Test)

\begin{tabular}{cccccccc}
\hline Items & Institute & $\mathbf{N}$ & Mean & SD & t & df & P \\
\hline \multirow{2}{*}{ Instructional planning } & CTEs & 103 & 42.8155 & 4.04811 & \multirow{2}{*}{$8.709^{*}$} & 202 & 0.000 \\
& Universities & 101 & 37.3069 & 4.94923 & & & \\
\hline
\end{tabular}


Tadesse Melesse

In order to see the presence of significance difference among the three Universities and CTEs in the use of instructional planning, one way ANOVA was employed and statistically significant difference was obtained $\left(F_{5,198}\right)$ $\left.=17.114,{ }^{*} p<0.05\right)$. For the mean comparisons, the Scheffe multiple comparison test clearly indicated that
Sci. Technol. Arts Res. J., Oct-Dec 2015, 4(4): 182-193

Begiemeder CTE used instructional planning better than others (44.39) followed by Woldia CTE (42.37) and Dessie CTE (41.92). Whereas, Wollo University with mean values (36.75), Debere Tabor University (37) and Woldia University (38.43) applied instructional planning less than the CTEs.

Table 2: Summary of One Way-ANOVA for the application of instructional planning between CTEs and Universities

\begin{tabular}{lccccc}
\hline & Sum of Squares & df & Mean Square & F & Sig. \\
\cline { 2 - 6 } Between Groups & 1710.522 & 5 & 342.104 & $17.114^{*}$ & 0.000 \\
Within Groups & 3957.890 & 198 & 19.989 & & \\
\hline Total & $\mathbf{5 6 6 8 . 4 1 2}$ & $\mathbf{2 0 3}$ & & & \\
\hline \multicolumn{5}{c}{$P<0.05$} \\
\end{tabular}

High-quality teacher preparation requires effective planning; a complex body of both academic and pedagogical knowledge; and multiple forms of assessment (Darling-Hammond et al., 2007; Goe, 2007). Higher Education Institutions are the main sources of the trained personnel by providing ingenious and wellorganized activities. However, as compared to sample Universities, sample CTEs were in a position to prepare instructional plans for their lesson delivery. The reason for this difference was the majority of the instructors of CTEs were from the education field having better pedagogical concepts. Besides CTEs were under the close inspection of the Regional Education Bureau. But most instructors of the universities were from the applied science field with less pedagogical background. They also have relatively higher academic freedom than CTEs and due to this no close inspection was made by higher officials. As a result, the emphasis they were giving to the application of instructional planning was less.

Over emphasizing on the disadvantages of the instructional plans, some instructors from Universities and CTEs also strongly argued that preparing instructional plans is simply wastage of time, energy and resources. For instance, interviewees from Woldia University strongly conjectured that:

They have many years of teaching experience. They know what they will do in the class. So, putting what they already know in a piece of paper is just duplication and wastage of time, energy and resources.

Instructors' experience and conception regarding instructional planning affects the way they are preparing themselves to the lesson delivery and the mode of assessment. For example, researchers found that when planning, experienced teachers make more extensive mental plans than written plans and rely less on curriculum materials than their less experienced counterparts (Livingston and Borko, 1990). Most instructors also believe that planning on a regular basis is boring and time consuming. Most of them were not eager to devote much time in designing a variety of challenging activities for their students, instead they made students promote to the next grades which they couldn't attain. Planning without interest through the direct order of the top officials could be superficial and unsatisfactory. Similar findings of Austin Independent School District (2010) posited that on careful inspection, the lesson design really do not support development of knowledge and skills that are expected of students. Others still argued that it is difficult to overstate the importance of planning. Planning limits students' free learning and it is not the end result (Peterson and Clark, 1978; Yelon and Schmidt, 1973 in Darling-Hammond and Bransford, 2005).

In contrast, many research findings (Borich, 1988; Danielson, 2007; Darling-Hammond and Bransford, 2005; Reece and Walker, 2003; Kasambira, 1993 in Marton and Saljo, 1997) implied that preparing instructional plans is important to show the direction where the teacher /instructor is going, what he/she is doing and why he/she is doing. Kasambira (1993) in Marton and Saljo (1997) further added that for any classroom teacher or instructor to attempt to teach a class without the assistance of the lesson plan is analogous to an airplane pilot's taking-off to a new destination without a cart. Instructional planning eliminates bias in classroom teaching, shows directions, avoids unnecessary repetitions of teachers (Borich, 1988); knows the 'entry behavior' of students, teaching methods and assessment techniques used by teachers (Gronlund, 2006; Reece and Walker, 2003); provides feedback (Gronlund, 2006) and motivates learners (Perkins, 1992). Therefore, the way of teacher's planning affects instruction and this in turn affects their reflection on practice and assessment (Danielson, 2007; Gronlund, 2006).

\section{Active Learning}

Under this part comparisons between Universities and CTEs and their faculties and departments were made regarding the application of different active learning methods.

Similarly comparisons were made among universities and colleges. In comparing Universities and CTEs in the implementation of different active learning techniques using Independent Sample T-Test, significant difference was not observed $(t=-.037, P>0.05$ at $d f=202)$.

Table 3: Mean differences on the application of active learning methods between Universities and CTEs (Independent Sample T-Test)

\begin{tabular}{cccccccc}
\hline Items & Institute & $\mathbf{N}$ & Mean & SD & t & df & P \\
\hline \multirow{2}{*}{ Active learning } & CTE & 103 & 45.3786 & 4.95295 & \multirow{2}{*}{0.037} & \multirow{2}{*}{202} & \multirow{2}{*}{0.971} \\
& University & 101 & 45.4059 & 5.57168 & & & \\
\hline
\end{tabular}


Table 4: Difference on the application of active learning methods by different faculties and departments (Summary of One way ANOVA)

\begin{tabular}{|c|c|c|c|c|c|}
\hline & Sum of Squares & df & Mean Square & $\mathbf{F}$ & Sig. \\
\hline Between Groups & 233.299 & 9 & 25.922 & & \\
\hline Within Groups & 5373.328 & 194 & 27.698 & 0.936 & .495 \\
\hline Total & 5606.627 & 203 & & & \\
\hline
\end{tabular}

The result of one way-ANOVA $\left.\left(F_{5}, 198\right)=.012, P>0.05\right)$ indicated no significant difference among the three Universities and three CTEs themselves.

Even though significant difference was not observed between and among universities and CTEs in applying active learning strategies in general, there were variations in exercising different active learning methods in their classroom practices. (see the table below).

Though different courses, contents and activities need different active learning methods, most instructors of Universities and CTEs still are applying the traditional methods of teaching (lecture method, 86 percent; question and answer method, 83 percent; demonstration, 55 percent). This clearly implies that instructors were not in a position to convey active learning methods properly. Similarly, the research findings of (Daniel, 2004; Dawit, 2008; Joshi and Verspoor, 2013; Reda, 2001) disclosed that although the constructivist approach has been well documented in the literature, its effective implementation in Ethiopian Higher Education is scant. Joshi and Verspoor (2013) further stated that still the Ethiopian classrooms remain primarily teacher-centered and the instructional practices in the universities and colleges are widely teacher-dominated and content-oriented (Daniel, 2004) and the current system of evaluating teaching effectiveness encourages such practice (Zenawi, 2009).

Table 5: Different active learning strategies frequently applied by instructors in percentage $(\mathrm{N}=204)$

\begin{tabular}{lclclc}
\hline Methods of teaching & $\%$ & Methods of teaching & $\%$ & Methods of teaching & $\%$ \\
\hline Lecture method & 86 & Case study method & 28 & Diamond ranking method & 19.2 \\
Discussion method & 83 & Classification & 26.5 & Think -pair- share method & 17 \\
Question and answer & 81 & Pyramiding method & 26 & Spider diagram method & 17 \\
Gapped lecture & 64 & Ice breaking method & 25.8 & Future wheel method & 13.5 \\
Demonstration & 55 & Reciprocal questioning & 25 & Inquiry method & 11 \\
Brain storming & 53 & Experiment method & 24.9 & Problem solving method & 8 \\
Independent work & 51 & Picture analysis & 24 & Hot seating method & 5 \\
Matching exercise & 48 & Role playing method & 24 & Golden fish bowl method & 3 \\
Project method & 41 & Field visit method & 22 & Mastery learning method & 2.8 \\
Debate & 38 & Model construction & 21 & Discovery method & 3.6 \\
& & & & Balloon Gaming method & 2 \\
\hline
\end{tabular}

Even though, the Education Policy of Ethiopia vividly portrayed that the pedagogical implications of constructivism- active learning methods or studentcentered teaching-would govern instructional practices in institutions (TGE, 1994), those active learning methods that require higher order thinking such as problem solving (8 percent), inquiry method (11 percent), mastery learning (2.8 percent) and discovery learning (3.6 percent) were not applied by most instructors of the Universities and CTEs. Nevertheless, analysis of existing research literature (Glasersfeld, 1989, cited in Kim, 2005; Narli, 2011; Prince, 2004) suggest that knowledge is not attained but constructed so students must do more than just listen and engage in such higher-order thinking tasks as analysis, synthesis, and evaluation. In addition, it is clear that most instructions in higher education are focused on the cognitive domain rather than the affective or psychomotor domains (Sperber, 2005). Regrettably, even within the cognitive domain much more attention is paid to the lower half of the domain (remembering, understating, and applying) than it is to the arguably more important upper half (analyzing, evaluating, and creating) (Reeves, 2006, citing Anderson, et al., 2001 taxonomy). Teaching and assessing the cognitive skills required for analysis, evaluation, and creation takes more time and effort than many university and college instructors feel they have (Reeves, 2006).
In order to enhance students' learning, the active involvement of the students should be in focus since quality teaching is based on the premise that all teachers should teach well and all students should learn well (Ramsden, 1992). He further stated that "the aim of teaching is simple: it is to make student learning". The learner is active when he/she is engaged mentally and motivationally in a task (Livingstone, 2001; Reece and Walker, 2003). Teachers should allow pupils to assume responsibility for their own learning process and educational reform must start with how students learn and how teachers teach, not with what students learn and what teachers teach (Kim, 2005). Students should not be seen as passive vessels to be filled with the knowledge provided by the faculty during lecture hours, but active constructors of knowledge and demonstrators of skills (Frazee et al, 1995; Reece and Walker 2003; Silberman, 1996).

\section{Continuous Assessment}

The result of one-sample t-test shows a significant difference between CTEs and Universities in the application of different continuous assessment techniques $\left(\mathrm{t}=2.778^{*}, P<0.05\right.$ at $\left.\mathrm{df}=202\right)$. That is, the mean value of CTEs (41.9369) is greater than the mean values of the Universities (40), revealing that CTEs were found to be better than the Universities in the application of different continuous assessment techniques. 
Table 6: Mean differences on the application of continuous assessment by instructors of Universities and CTEs (Independent t-Test)

\begin{tabular}{cccccccc}
\hline Items & Institute & $\mathbf{N}$ & Mean & SD & t & df & $\mathbf{P}$ \\
\hline \multirow{2}{*}{ Continuous Assessment } & CTE & 103 & 41.9369 & 5.13431 & \multirow{2}{*}{$2.778^{\star}$} & \multirow{2}{*}{202} & \multirow{2}{*}{006} \\
& University & 101 & 40.0000 & 4.81456 & & & \\
\hline
\end{tabular}

On the other hand, the results of one way-ANOVA implied that there was no significant difference among the three CTEs and three Universities themselves $\left(F_{5}, 198\right)$ $=2.178, P>.05$. Even though sample CTEs were found to be better than Universities in the application of continuous assessment, the focus of both the universities and colleges on assessment for learning (formative assessment) was very low. They were highly concentrated on assessment of learning (summative assessment). A variety of continuous assessment strategies such as independent work, practical tasks, reflective activities, portfolios, demonstration performances, authentic assessment, peer and selfassessment were not worthily applied. The data obtained through interviews and focus group discussion also revealed the same.

Table 7: Summary of One Way-ANOVA: Differences of the three Universities and CTEs in applying continuous assessment

\begin{tabular}{lllcccc}
\hline \multirow{2}{*}{ Between Groups } & Sum of Squares & df & Mean Square & F & Sig. \\
\cline { 2 - 3 } Within Groups & 270.996 & 5 & & 54.199 & \multirow{2}{*}{2.178} & \multirow{2}{*}{058} \\
\cline { 1 - 3 } Total & 4927.155 & 198 & 24.885 & & & \\
\hline
\end{tabular}

The interview results of some instructors from Debre Tabor and Wollo Universities, for instance, elucidated that:

Most of the time, they used few techniques of continuous assessment such as repeated paper and pencil tests, group assignments and final examinations. These assessment techniques were applied basically for grading purpose. Due to large class size, overloaded works, shortage of time, and lack of commitment formative continuous assessment was not significantly applied.

Assessment has many purposes in higher education ranging from narrow, formative ones to broad, summative ones (Reeves, 2006). It is a crucial element of the instructional process. Carefully designed assessment is a powerful tool for educators to improve the teachinglearning process (Bain, 2004; James et al., 2002; Reeves, 2006). More specifically, assessment for learning is seen as an integral aspect of the teaching and learning cycle that helps to improve students' achievement (Black and Wiliam, 1998; Bain, 2004; Brookhart, 2004; Elwood and Klenowski, 2002; Gronlund, 2006; Wlodkowski and Ginsberg, 1995) and the quality of teaching (Austin, 1993; Ramsdon, 1992).

However, the research finding proved that different continuous assessment exercises in many programs were poor in terms of giving feedback and in motivating further learning. Mainly university instructors were not concerned with assessment for learning. Much focus was given for grading than feedback. Similar findings revealed that even though portfolios, self and peer assessment, simulations and other innovative methods were introduced in higher educational contexts (Struyven et al., 2005), in practice, both in universities and colleges, the use of different continuous assessment techniques and their feedback were not satisfactory (Singh, 2006). Thus, the suggestion of (Bain, 2004:151) which says "instructors of universities and colleges use assessment to help students learn, not just rate and rank their efforts" should be emphasized.
Better assessment and enhanced alignment in university and college teaching and learning will require a larger investment in assessment and evaluation than most institutions are expending at this time (Reeves, 2006). Since assessment and instruction are aligned, assessment influences instruction either positively or negatively. The nature of teacher's assessment predicts teachers' methods of teaching-surface or deep (Gronlund, 2006) and students' perceived assessment requirements (Napoli and Raymond, 2004; Ramsdon, 1992). Ramsden (1992) indicated that inappropriate assessment procedures encourage surface approach to learning, yet varying the alternative assessments evoke deep approaches to learning. Assessment also drives learning (Napoli and Raymond, 2004). Most students come to recognize that they can get good grades by cramming for tests and then quickly forgetting what they have memorized to allow themselves to focus on other pursuits (Reeves, 2006). Therefore, instead of focusing on final grading, assessment should be used for checking the learners' readiness, their achievement about the expected goals and the effectiveness of the teaching approaches that should be in place (Brookhart, 2004; USAID, 2010).

On the other hand, the other focus group discussants from Dessie and Begiemeder CTE, regarding the application of continuous assessment, itemized that:

Even though we used different continuous assessment techniques, it was not dictated by their instructional plans (daily lesson plan and course plan). We lacked remembering and joining what is planned and what is expected to measure \& achieve.

The result above indicated that even though instructors are using different continuous assessment techniques, they were not guided by their lesson objectives. Mostly, the objectives they stated in their plans were not congruent with the assessment techniques they applied. This entails that most instructors conducted assessment haphazardly. Similarly, to Reeves, (2006) evaluations of traditional and blended approaches to post- 


\section{Tadesse Melesse}

secondary teaching indicate that the most commonly misaligned factor among objectives, contents and instructional design is assessment. Simply put, instructors may have supercilious goals, share high-quality content, and even utilize advanced instructional designs, but most assessment strategies tend to focus on what is easy to measure rather than what is important (Reeves, 2006). Assessment strategies are the methods used to estimate student accomplishment of the course objectives. Historically, this has been one of the weakest aspects of both traditional and innovative course design and implementation in higher education (Shipman et al., 2003 in Reeves, 2006). In most undergraduate courses, assessment and grading are usually based upon multiplechoice tests or academic essays (Reeves, 2006).

Generally, an effective instructor always strives for his/ her students achieve the stated objectives using a variety of active learning methods and finally assessments should check whether the designed objectives were achieved or not (Brookhart, 1999; Reeves, 2006). If scholars want their university and college graduates to possess the 21st
Sci. Technol. Arts Res. J., Oct-Dec 2015, 4(4): 182-193

century skills, assessment must focus on those higher order types of outcomes such as critical thinking, problem solving, creativity, curiosity, concern for ethical issues as well as breadth and depth of specific knowledge and the methodologies and standards of evidence used to create that knowledge (Bain, 2004). Accordingly, university and college teachers must devote much more effort to the task of assessment because it is the lifeblood of good teaching (Blumenstyk, 2006). Rather than using just one method, robust assessment requires the critical analysis of multiple forms of evidence that learning outcomes have been attained (Reeves, 2006).

\section{Conceptions on Effective Teaching}

The T-Test result implied that there was no significant difference on the conceptions instructors have regarding effective teaching on institutes (between CTEs and Universities). ( $\mathrm{t}=-.180, P>0.05$ at $\mathrm{df}=202)$. That is, the mean values of CTEs (32.6408) and Universities (32.7624) regarding the conceptions of effective teaching were nearly the same.

Table 8: Mean differences on the conceptions of effective teaching between Universities and CTEs (Independent Sample t-Test)

\begin{tabular}{cccccccc}
\hline Items & Institute & $\mathbf{N}$ & Mean & SD & t & df & P \\
\hline \multirow{2}{*}{ Conceptions on Effective Teaching } & CTE & 103 & 32.6408 & 5.00167 & \multirow{2}{*}{180} & \multirow{2}{*}{202} & \multirow{2}{*}{0.857} \\
\cline { 2 - 8 } & University & 101 & 32.7624 & 4.60901 & &
\end{tabular}

The results of one way-ANOVA also implied that there was no significant difference among the three CTEs and three Universities $\left(F_{5,198}\right)=.040, P>0.05$. Despite the fact that statistically significant difference was not observed between Universities and CTEs and among universities and CTEs, individual instructor's conceptions and understandings concerning effective teaching varied.

Table 9: Summary of One Way-ANOVA: Differences of faculties and departments on conception of effective teaching among the three Universities and CTEs

\begin{tabular}{cccccc}
\hline & Sum of Squares & df & Mean Square & F & Sig. \\
\cline { 2 - 5 } Between Groups & 4.769 & 5 & .954 & \multirow{2}{*}{040} & .999 \\
Within Groups & 4671.991 & 198 & 23.596 & & \\
\hline Total & $\mathbf{4 6 7 6 . 7 6 0}$ & $\mathbf{2 0 3}$ & & &
\end{tabular}

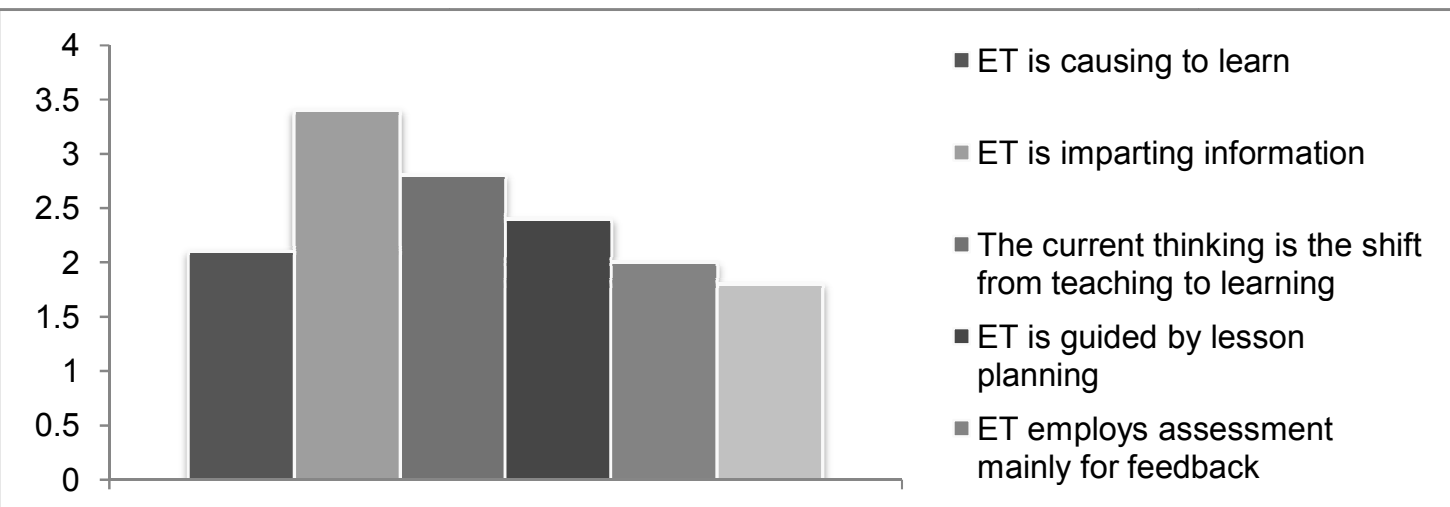

Figure 2: A graph representing conceptions of effective teaching

By most instructors, the concept of effective teaching is not well addressed. Most instructors considered effective teaching as imparting information. That is why they were exercising dominantly teacher-centered approaches. Similar findings of Zenawi et al. (2011) revealed that teacher-centered conception is the predominant orientation and teaching and learning practices have been described to be reflections of this orientation; and the measure of teaching effectiveness currently in use reflects the teacher-centered paradigm (Joshi and Vespoor, 2013).

Teacher-centered orientation is less likely to produce high-quality learning outcomes among students (Akerlind, 
Tadesse Melesse

2004). Educators, researchers, and policymakers concur that the traditional view of learning, focused on knowledge and procedures of low cognitive challenge and the regurgitation of superficial understanding, does not meet the demands of the present and future (Danielson, 1996). Our society today needs young people who are flexible, creative and proactive, who can solve problems, make decisions, think critically, communicate ideas effectively and work efficiently within teams and groups. In order to optimize life-long learning and potential success, it is now widely accepted that young people need to have opportunities to develop personal capabilities and effective thinking skills as part of their well-rounded education. By using active learning methodologies it is hoped that pupils will not only come to a deeper understanding of the issues involved, but also that their motivation and enthusiasm will be heightened (Danielson, 1996; Silberman, 1996). Besides, effective teaching is using assessment for learning as a feedback so as to improve the teaching-learning process was found to be low. Effective teaching is meant conducting the lesson guided by the instructional plan was also found to be lower. Based on such dimensions, most instructors (both in the universities and CTEs) did not consider themselves as effective practitioners.

Nevertheless, a large number of instructors understand that the current thinking is the shift from teaching to learning but practice doesn't manifest this. In order to sustain lifelong learning, it is learners who should actively participate in the learning process and the role of the instructor is facilitating, guiding and creating conducive environment for learners. This shift encourages teachers to reflect not only on the key principles of learning and teaching but also on their role in the process. Recent research on effective teaching (Bransford, 1999; Lampert, 2002 in Reece and Walker, 2003) indicated that engagement with students on a personal level; excellent subject matter knowledge and purposeful teaching are some features of effective teaching behaviors.

\section{Factors Affecting the Instruction Process}

Data obtained from open ended questionnaire, interviews and focus group discussions regarding factors affecting the overall implementation of the instructional process disclosed that: lack of interest and commitment to conduct instructional plans or attitudinal problems (i.e most instructors believe that preparing a lesson plan is wastage of time); lack of knowledge in implementing different active learning strategies (mostly for those from the applied field of the universities); over load works of instructors (both horizontally and vertically); large class size and shortage of time; instructors focus mainly on assessment of learning than assessment for learning were the identified impeding factors.

\section{CONCLUSIONS}

The instructional process comprises three basic interactive components (planning, teaching and assessment) that are integrated one another (Brookhart, 2004; Brookhart, 1999; Clarke, 2005; Reeves, 2006) and the success of any learning environment is determined by the degree to which there is adequate integration among these critical factors (Reeves, 2006). Effective teaching in Higher Education is about achieving the planned programs and on top of this bringing learning into effect. Quality instruction involves primarily instructional planning and managing learning effectively, and then using a
Sci. Technol. Arts Res. J., Oct-Dec 2015, 4(4): 182-193

variety of active learning strategies and finally assessing students' learning experiences properly.

In the instructional process, the first task of teacher or instructor is planning learning. Planning involves the establishment of instructional objectives, processes and learning outcomes which leads to decisions about the types of learning activities that will enable students to successfully achieve the required outcomes. Therefore, as Higher Education Institutions (universities and CTEs) are the creators of the learned society, the instructional processes should be guided by the instructional plans and the continuous assessment mechanisms should be in line with the stated objectives (entry behavior) of students set in the instructional plans.

Currently, in Higher Education, there is a shift from teacher centered to learner centered approach and from teaching to learning. Thus in a contemporary Higher Education context, effective teaching is enabling learners to become an independent learner, develop metacognitive skills, solve problems, acquire generic study skills, make effective use of technology to promote one's own learning, and work effectively with others. The student-centered approach, focusing on the process of learning rather than the product is a central idea for effective teaching. Therefore, in universities and CTEs those active learning strategies that demands higher order thinking and enabling learners learn by themselves should be in place.

Integral to the concept of instructional planning and methods of teaching is continuous assessment. Continuous assessment is a strategy used by teachers to support the attainment of goals and skills by learners over a period of time and to inform about teaching-learning, the achievement of learning objectives and competencies. Best instructors in Higher Education use formative continuous assessment to help students learn, not just rate and rank their efforts. Formative assessment is the garden equivalent of feeding and watering the plants directly affecting their growth and development. But summative assessment of the plants is the process of simply measuring them which do not affect the growth of the plants. Therefore, in order to make students grow and develop in their academic potential through continuous feedback, both University and CTE instructors should primarily implement assessment for learning (formative assessment) more than assessment of learning (summative assessment).

Now days the paradigmic shifts in teaching are from teaching to learning, from assessment of learning to assessment for learning and from knowledge reproduction to knowledge production. Though conceptions regarding effective teaching vary among instructors of the Universities and CTEs, instructors should focus and have of great interest on teaching learning or learning how to learn rather than disseminating knowledge. They should also emphasize on enabling learners produce their own knowledge and creativity. Since the target of effective teaching is how to make students learn.

Instructors' attitudinal problems to conduct instructional plans; lack of knowledge to implement different active learning strategies (mainly for those from the applied field of the universities); work load and large class size were taken as major factors affecting the 


\section{Tadesse Melesse}

effectiveness of the instructional processes. Therefore, capacity building trainings up on these challenges should be provided in a more sensible manner.

\section{Acknowledgments}

I would like to thank Woldia University for funding the research budget and to Mr. Getachew Kebede, Dean, the Educational and Behavioral Sciences Faculty, for his constructive comments and suggestions on the statistical applications. Besides, my heartfelt thanks also go to those research respondents particularly instructors, department heads and deans of the three universities and CTEs for their unreserved cooperation and contributions in providing valuable information.

\section{Conflict of Interest}

None declared.

\section{REFERENCES}

Akerlind, G.S., (2004) 'A new dimension to understanding university teaching'. Teaching in Higher Education 9(3): 363-375.

Akyeampong, K., Pryor, J. and Ampiah, J. (2006). A vision of successful schooling: Ghanaian teachers' understandings of learning, teaching and assessment. Comparative Education 42(2): 155-176.

Allan, J. and Clarke, K. (2007). Nurturing supportive learning environments in HE through the teaching of study skills: To embed or not to embed? International Journal of Teaching and Learning in HE 19(1): 64-76.

Austin Independent School District.(2010). Planning for Rigor. Department of Language Arts.

Austin, A.W. (1993). Assessment for Excellence. The Philosophy and Practice of Assessment and Evaluation. New York: Macmillan.

Bain, K. (2004). What the Best College Teachers Do, Cambridge, MA: Harvard University Press.

Black, P. and Wiliam, D.(1998). Assessment and Classroom Learning. Assessment in Education 7-74.

Blumenstyk, G. (2006). Businesses have remedies for sale, but a cure is not guaranteed'. The Chronicle of Higher Education B30-B32.

Bonwell, C.C., and Eison, J.A. (1991). Active learning: Creating Excitement in the Classroom (ASHE ERIC Higher Education Report No. 1). Washington, DC: Association for the Study of Higher Education.

Borich, G. D. (1988). Effective Teaching Methods. Columbus: Merrill Publishing Company.

Brookhart, P.(1999). The Role of Assessment in Instruction. Jones and Bartlett publishers.

Brookhart, S.M. (2004). Classroom assessment: Tensions and intersections in theory and practice. Teachers College Record 106: 429-458.

Brown, S. and Knight, P. (1994). Assessing Learners in Higher Education. London: Kogan Page.

Bryk, A., Harding, H., and Greenberg, S. (2012). Contextual influences on inquiries into effective teaching and their implications for improving student learning. Harvard Educational Review, 82, 83-106.

Calderhead, J. and Shorrock, S.B. (1997). Understanding Teacher Education. Case Studies in the Professional
Sci. Technol. Arts Res. J., Oct-Dec 2015, 4(4): 182-193

Development of Beginning Teachers. London: The Falmer Press.

Clarke, S. (2005). Formative assessment in the secondary classroom. London: Hodder Murray.

Creswell, J.W. (2012). Educational Research. Planning, Conducting and Evaluating Research ( $4^{\text {th }}$ ed.). Boston: Pearson Education, Inc.

Daniel Desta. (2004). Observations and Reflections of the Higher Education Teachers on the Quality of Teaching and Learning in Higher Education in Ethiopia. The Ethiopian Journal of Higher Education 1(1): 63-81.

Danielson, C. (1996). Enhancing Professional Practice. A Frame work for Teaching.(1st ed.). Virginia: Association for Supervision and Curriculum Development. USA. Virginia.

Danielson, Charlotte (2007). Enhancing Professional Practice. A Frame work for Teaching. (2 ${ }^{\text {nd }}$ ed.). Association for Supervision and Curriculum (ASCD). Alexandria: Virginia.

Darling-Hammond, L. and Bransford, J. (2005).(Eds.) Preparing Teachers for a Changing World: what Teachers should Learn and be able to do. USA: Jossy-Bass Education Series.

Darling-Hammond, L. (2006). Constructing $21^{\text {st }}$ Century Teacher Education. Journal of Teacher Education 57(3): 300-314.

Darling-Hammond, L., Holtzman, D.J., Gatlin, S.J. and Heilig, J.V. (2005). Does teacher preparation matter? Evidence about teacher certification, teach for America, and teacher effectiveness. Education Policy Analysis Archives, 13. Retrieved on June, 2014. http://epaa.asu.edu/epaa/v13 n421.

Dawit Mekonnen. (2008). Prospective and In-service Teachers' Thinking about Teaching and Learning: A Metaphorical analysis. Ethiopian Journal of Education 28(1): 49-72.

Denscombe, M. (2008). Communities of Practice: A Research Paradigm for the Mixed Methods Approach. Journal of Mixed Methods Research. 2(3): 270-283.

Education and Training Policy (1994). Federal Democratic Republic of Ethiopia: Addis Ababa.

Entwistle, N. (1994). Adult Study Strategies. In T. Hussen and T.N. Postlethwaite (Eds.), The International Encyclopedia of Education (pp.184-194). London: Pergamum.

Entwistle, N.J. and Entwistle, A. (1991). Contrasting forms of Understanding for Degree Examinations: The Student Experience and its Implications. Higher Education 22: 205-227.

Frazee, M.B. and Rudnitski A.R. (1995). Integrated Teaching Methods: Theory, Classroom Application, and FieldBased Connections (Education). Delmar Publication.

Getachew Kebede. (2013). Perceptions of Woldia University Instructors towards Classroom Assessment Practices: Implications for Quality of Education. Woldia University, Faculty of Education and Behavioral Sciences. Woldia. (Unpublished paper)

Goe, L. (2007). The link between teacher quality and student outcomes: A research synthesis. Washington, DC: National Comprehensive Centre for Teacher Quality. Retrieved December 20, 2013, from http://www.ncctq. org/publications/ 


\section{Tadesse Melesse}

Gronlund, N.E. (2006). Assessment of student achievement (8th ed.). Boston: Pearson.

Herrington, J. and Oliver, R. (2000) 'An instructional design framework for authentic learning environments', Educational Technology Research and Development 48(3): 23-48.

Hersh, R.H. and Merrow, J. (2005) Declining by Degrees: Higher Education at Risk, New York: Palgrave Macmillan.

Huisheng, T. (2007). Educational wisdom and intellectual teachers are called on by the times. Frontiers of Education in China 2(1):119-132.

Hussein, J.W. (2007) Developing teacher educators: a technocratic rationality versus critical practical inquiry-the Ethiopian experience, Journal of In-Service Education, 33(2):209-235.

Johnson, B. and Christensen, L. (2008) Educational Research: Quantitative, Qualitative and Mixed Approaches. Los Angeles, CA et al.: Sage Publications.

Johnson, D. W., Johnson, R. T., and Smith, K. (1991). Cooperative Learning: Increasing College Faculty Instructional Productivity (ASHE-ERIC Higher Education Report No. 4). Washington, DC: Association for the Study of Higher Education.

Joshi, R. and Verspoor, A. (2013). Secondary education in Ethiopia: Supporting growth and Transformation. Washington DC: The World Bank.

Keeves, J.P. (1994). Assessment in Schools: In: T. Hussen and T.N. Postlethwaite (Eds.), The International Encyclopedia of Education (pp. 362-370). London: Pergamon.

Kim, J.S. (2005). The Effects of a Constructivist Teaching Approach on Student Academic Achievement, Selfconcept, and Learning Strategies. Asia Pacific Education Review 6(1): 7-19.

Leinhardt, G. (1983). Routines in Expert Math Teachers' Thoughts and Actions. Paper presented at the annual meeting of the American Educational Research Association, Montreal, Canada. (ERIC Document Reproduction Service No. ED234980).

Lemov, D. (2010). Teach like a Champion: 49 Techniques that put students on the path to college. San Francisco, CA: Jossey-Bass.

Livingston, C. and Borko, H. (1990). High School Mathematics Review Lesson: Expert-novice distinctions. Journal for Research in Mathematics Education 21: 372387.

Livingstone, G. (2001). Taking Teacher Education Forward: Ten Steps towards Quality a Report. MoE, Addis Ababa.

Marczyk, G., DeMatteo, D., and Festinger, D.(2005). Essentials of Research Design and Methodology. A Practical Overview of Proven Methods for Research Design. USA: John Wiley and Sons, Inc.

Mertens, D. (2007). Transformative Paradigm Mixed Methods and Social Justice. Journal of Mixed Methods Research 1(3): 212-225.

Meyers, C., and Jones, T. (1993). Promoting Active Learning: Strategies for the College Classroom. San Francisco: Jossey-Bass.

Miller, R. (2005). Integrative learning and assessment. Peer Review 7(4):11-14.
Sci. Technol. Arts Res. J., Oct-Dec 2015, 4(4): 182-193

Ministry of Education (MoE). (2003). Teacher Education System Overhaul (TESO): Handbook. Addis Ababa: Author.

Ministry of Education (MoE). (2008b). Terms of reference for secondary teacher education curriculum framework. Addis Ababa: Author

MoE (2009). Postgraduate Diploma in Teaching (PGDT) Curriculum Framework for Secondary School Teacher Education Program in Ethiopia. Addis Ababa. Ministry of Education.

Napoli, A.R. and Raymond, L.A. (2004). How reliable are our assessment data?: a comparison of the reliability of data produced in graded and un-graded conditions. Research in Higher Education 45(8): 921-929.

Newman, F.M. and Wehlange, G.G. (1995). Successful School Restructuring. Madison: University of Wisconsin.

Osguthorpe, R.D. (2008). On the reasons we want teachers of good disposition and moral character. Journal of Teacher Education 59(4): 288-299.

Perkins, D. N. (1992). Smart Schools: Better Thinking and Learning for Every Child. New York: The Free Press.

Popham, W.J. (2008). Transformative Assessment. Alexandria, VA: ASCD.

Ramsden, P.(1992). Learning to Teach in Higher Education. London: Rutledge and Falmer.

Reda Darge (2001) Conceptions of Constructivist Teaching Approaches in Higher Education: A Case study. Institute of Educational Research 9(1): 57-94

Reece, I. and Walker, S. (2003). Teaching, Training and Learning: A Practical Guide Incorporating FENTO Standards $\left(5^{\text {th }} \quad\right.$ ed. $)$. Business Education Limited Publishers.

Reeves, T.C. (2006). How do you know they are learning?: The importance of alignment in higher education. International Journal of Learning Technology 2(4): 294308.

Rohrer, D., and H. Pashler. (2010). Recent research on human learning challenges conventional instructional strategies. Educational Researcher 39, no. 5: 406-12.

Shulman, L. S. (1987). Knowledge and Teaching: Foundations of the New Reform. Harvard Educational Review, 57(1), 1-22.

Silberman, M. (1996). Active Learning: 101 Strategies to Teach any Subject. Boston: Allyn and Bacon.

Singh, R.R. (2006). Measurement and Evaluation in Education. New Delhi: Shree publishers and Distributors

Sokoloff, D. R., and Thornton, R. K. (1997). Using Interactive Lecture Demonstrations to Create an Active Learning Environment. The Physics Teacher 35: 340-347.

Sperber, M. (2005). How undergraduate education became college lite -and a personal apology', in R.H. Hersh and J. Merrow (Eds.) Declining by Degrees: Higher Education at Risk, New York: Palgrave Macmillan.

Struyven, K., Dochy, F. and Janssens, J. (2005). Students Perceptions about Evaluation and Assessment in Higher Education: A Review. Assessment and Evaluation in Higher Education 30(4): 331-347.

Tadesse Melesse .(2012). Leadership Effectiveness of the School Principals and their Role for Quality Education. Dessie . (unpublished). 


\section{Tadesse Melesse}

Teddlie, C. and Tashakkori, A. (2009). Foundations of Mixed Methods Research: Integrating Quantitative and Qualitative Approaches in the Social and Behavioral Sciences. Thousand Oaks CA: Sage.

Tesfaye Semela (2014) Teacher preparation in Ethiopia: a critical analysis of reforms, Cambridge Journal of Education 44(1): 113-145.

Tessema, K.A. (2006). Contradictions, Challenges and Chaos in Ethiopian Teacher Education, Journal of Critical Education Policy Studies. Retrieved on June, 2014: www.jceps.com.

Thomson, M.M. and Mclntyre, M. (2013). Prospective teachers' goal orientation: an examination of different teachers' typologies with respect to motivations and beliefs about teaching, Teacher Development: An International Journal of Teachers' Professional Development 17(4): 409-430.

UNESCO (2006). Cross-Cultural Studies of the Quality of Education: Planning their Design and Managing their Impact. UNESCO: International Institute for Educational Planning. Available at www.unesco.org/iiep
Sci. Technol. Arts Res. J., Oct-Dec 2015, 4(4): 182-193

USID/IQPEP. (2010). Teachers Handbook on Formative Continuous Assessment. Grade Four. Addis Ababa: Commercial Printing Enterprise.

Wiliam, D. and M. Thompson. (2008). Integrating assessment with learning: What will it take to make it work? In The Future of Assessment: Shaping Teaching and Learning. New York: Erlbaum.

Wlodkowski, R.J. and Ginsberg, M.B. (1995). Diversity and Motivation: Culturally Responsive Teaching. San Francisco: Jossey- Bass.

Yorke, M. (2003). Formative Assessment in Higher Education: Moves towards Theory and the Enhancement of Pedagogic Practice. Higher Education 45(4): 477-501.

Zenawi, Z. (2009). Validating the student ratings of teaching using multiple measures', paper presented at the 1st International Conference on Educational Research for Development, Addis Ababa, Ethiopia, 13-15 May.

Zenawi, Z., Beishuizen, J.and Van Os, W.(2011) Conceptions and practices in teaching and learning: implications for the evaluation of teaching quality. Quality in Higher Education 17(2): 151-160.

Zhang, B. (2003). Using student-centered teaching strategies in calculus. The China Papers 2:100-3. 